\title{
Salmonella Infection in Green Anoles (Anolis carolinensis), an Invasive Alien Species on Chichi Island of the Ogasawara Archipelago in Japan
}

\author{
Daisuke SUMIYAMA ${ }^{1,3)}$, Hidemasa IZUMIYA ${ }^{2)}$, Tomoko KANAZAWA ${ }^{1)}$ and Koichi MURATA ${ }^{1) *}$ \\ ${ }^{1)}$ Laboratory of Wildlife Sciences, College of Bioresource Sciences, Nihon University, 1866 Kameino, Fujisawa, Kanagawa \\ 252-0880, Japan \\ 2) Department of Bacteriology I, National Institute of Infectious Diseases, 1-23-1Toyama, Shinjuku-ku, Tokyo 162-8640, Japan \\ ${ }^{3)}$ International Institute of Avian Conservation Science, Management of Nature Conservation, Department of The President's Affairs, \\ Dana Tower M1, Street 32, Khalidia, P.O. Box 47087, Abu Dhabi, United Arab Emirates
}

(Received 27 April 2013/Accepted 11 November 2013/Published online in J-STAGE 25 November 2013)

ABSTRACT. We investigated the presence of Salmonella in the green anole (Anolis carolinensis), an invasive alien species on Chichi Island, Japan. Samples were also collected from feral goats and public toilets on the island to examine infectious routes. Salmonellae were isolated from $27.1 \%$ of 199 samples; $32.6 \%$ of 141 cloacal samples from anoles, $62.5 \%$ of 8 intestinal samples from anole carcasses, $16.7 \%$ of 12 fecal samples from goats and $2.6 \%$ of 38 toilet bowl swabs. The serotype of most isolates was Salmonella Oranienburg (94.4\% of 54). Although we did not confirm the infection pathways, our results indicated that green anoles are a risk factor as a source of Salmonella for public health. It is important to consider endemic pathogens that may be amplified by alien species within their introduced areas. KEY WORDS: green anole, invasive alien species, lizard, reptiles, Salmonella Oranienburg.

doi: 10.1292/jvms.13-0217; J. Vet. Med. Sci. 76(3): 461-465, 2014

Recently, invasive alien species have become widespread in Japan. Their impact on ecosystems as competitors for food and habitat and as predators of endemic and endangered animals has been demonstrated $[9,25]$. They also cause serious damage to agriculture resulting in countermeasures being taken to control the populations. Although these species are a potential risk for introducing infectious diseases to humans by acting as reservoirs, there are only a few proposals in Japan to control the transport and amplification of these pathogens [11] and no published studies on zoonotic pathogens carried by alien lizards.

The green anole (Anolis carolinensis) is an arboreal lizard that originally inhabited regions in North America and was then introduced to Guam [4, 6] and Hawaii [1] in the 1950s and Chichi Island in the 1960s [18, 20]. The lizards have impacted negatively on the ecosystems of Chichi Island [21]. In this study, we conducted a surveillance study focused on Salmonella, zoonotic bacteria that are isolated at a high rate from reptiles. The object of this study was to evaluate the risks of pathogenic microorganisms being carried by an alien species, namely the green anole, to gain information for public health.

The survey was carried out on Chichi Island, located at $27^{\circ} 05^{\prime} \mathrm{N}$ and $142^{\circ} 11^{\prime} \mathrm{E}$ (Fig. 1). Samples were collected at

\footnotetext{
*Correspondence to: Murata, K., Laboratory of Wildlife Sciences, College of Bioresource Sciences, Nihon University, 1866 Kameino, Fujisawa, Kanagawa 252-0880, Japan.

e-mail:k-murata@brs.nihon-u.ac.jp

(C)2014 The Japanese Society of Veterinary Science
}

This is an open-access article distributed under the terms of the Creative Commons Attribution Non-Commercial No Derivatives (by-ncnd) License $<$ http://creativecommons.org/licenses/by-nc-nd/3.0/>. six different places (Fig. 1). Sampling was performed with the cooperation of the Japan Wildlife Research Center, under the permission of the Ministry of the Environment, for 5 days a month during 2007 to 2009 (Table 1). Especially, the area near Ohgami-yama Park has a high population density, and the other locations have only a few inhabitants.

Cloacal samples were collected from 141 green anoles found in 5 locations and one unidentified location (Fig. 1 and Table 1) placed immediately in Seed Swab $\gamma$ No. 1 Eiken transport medium (Eiken Chemical Co., Ltd., Tokyo, Japan) and stored at $4{ }^{\circ} \mathrm{C}$ until laboratory examination. Eight green anole carcasses of unknown origin preserved frozen at the Japan Wildlife Research Center were transported to our laboratory and defrosted, and the large intestine contents were collected. We also collected 38 swabs from eight public lavatories (toilet bowl) at 3 places and 12 fecal samples from feral goats (Capra hircus), the other invasive alien species on the island at 3 locations (Fig. 1 and Table 1).

All samples were examined for Salmonella spp. by transferring into $10 \mathrm{ml}$ Enterobacteriacae Enrichment Mannitol Broth, followed by incubation at $37^{\circ} \mathrm{C}$ for $24 \mathrm{hr}$. One $\mathrm{m} l$ aliquot of each culture was then transferred to $9 \mathrm{~m} l$ Rappaport-Vassiliadis broth and incubated at $42^{\circ} \mathrm{C}$ for 20 hr. And then, these samples were cultured on SalmonellaShigella agar with colonies screened for Salmonella using triple sugar iron and lysine indole motile media, followed by identification using the ID-Test·EB-20 system (Nissui Pharmaceutical Co., Ltd., Tokyo, Japan). Serotyping was carried out according to the Kauffmann and White scheme (Denka Seiken Co., Ltd., Tokyo, Japan). PFGE was performed using S. enterica serovar Braenderup H9812 as the standard [8] with 17 samples included in the analysis according to year, location and source of sampling (Fig. 2 and Table 1). The resulting profiles were interpreted by visual analysis, and 


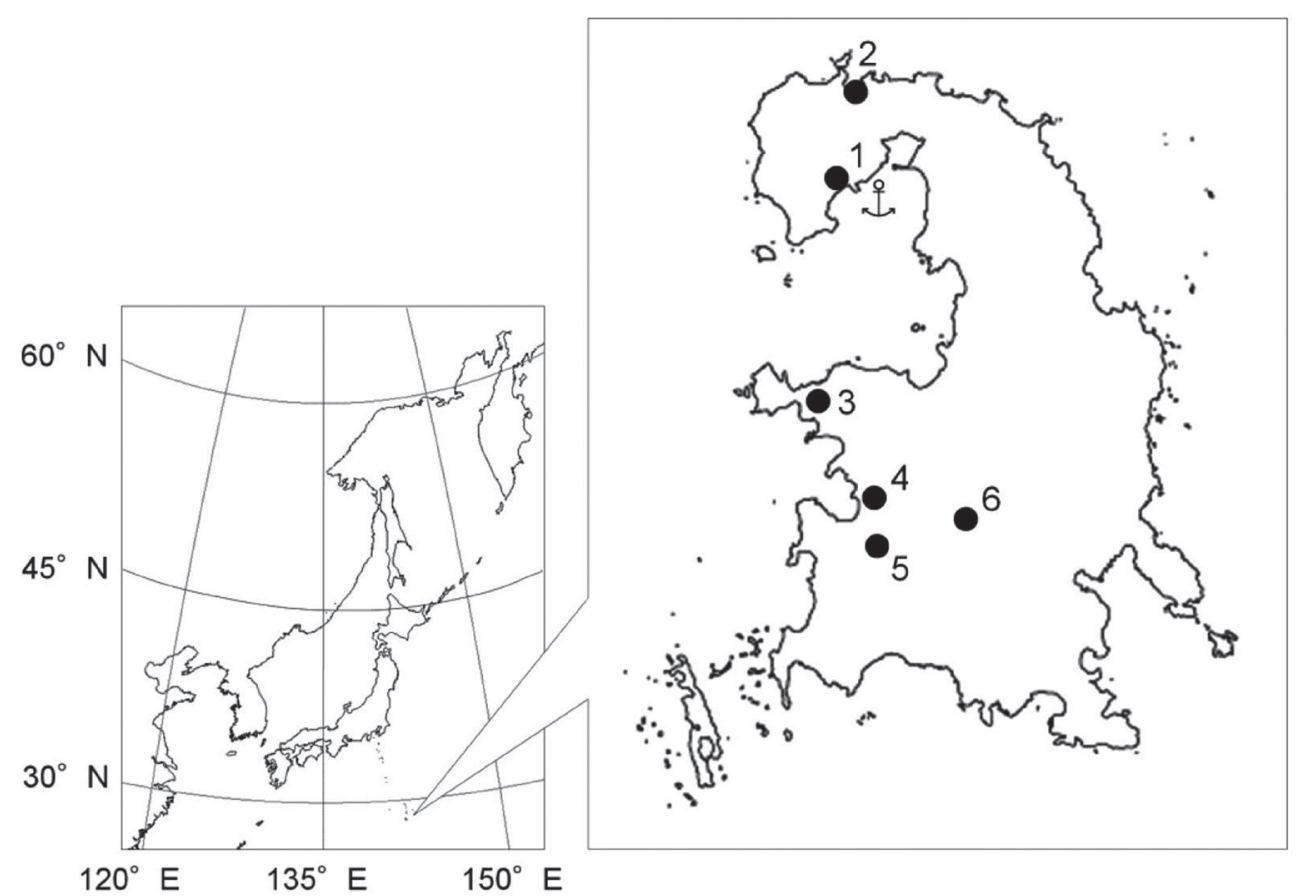

Fig. 1. Location of Chichi Island with the Ogasawara archipelago and the sampling sites on the island. The numbers in the figure indicates the following site locations: 1, Ohgami-yama Park; 2, Miyano Beach; 3, Kominato; 4, Suzaki; 5, Nakayama Pass; 6, Shigure Dam. The anchor symbol indicates the location of the main port of Chichi island.

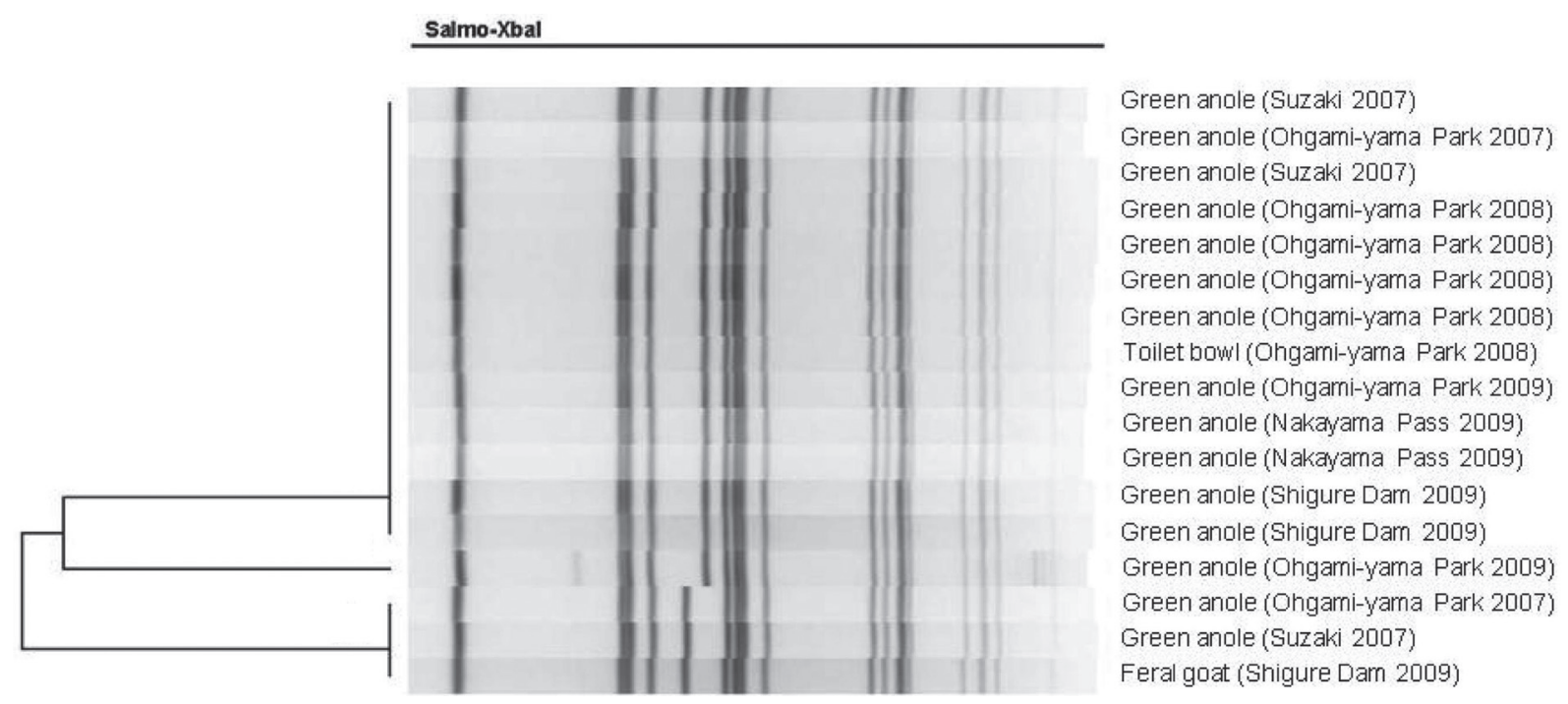

Fig. 2. PFGE profiles of Salmonella Oranienburg from samples collected in several locations on the island. The PFGE patterns were classified into only one type.

profile photographs were then scanned and analyzed using BioNumerics software (Applied Maths NV, Sint-MartensLatem, Belgium). Similarities were determined using the Dice coefficient with clustering based on the unweighted pair group method using arithmetic averages and a band position tolerance of $1.2 \%$ [19]. Statistical analysis was performed using $\chi^{2}$ tests for independence which were used to evaluate differences in Salmonella prevalence in cloacal samples collected in different years and places using JMP 9.0 (SAS Institute, Tokyo, Japan). To assess differences in prevalence between the sampling locations, we omitted 29 cloacal samples collected in 2008 as the location of these 
Table 1. Isolation of Salmonella in cloacal samples from green anoles to location and year of sampling

\begin{tabular}{|c|c|c|c|c|c|c|c|c|c|}
\hline \multirow{2}{*}{$\begin{array}{l}\text { Samples and } \\
\text { month/year of } \\
\text { sampling }\end{array}$} & \multicolumn{8}{|c|}{$\%$ of isolation (positive samples/total samples examined) of Salmonella by area on the island } & \multirow{2}{*}{$\begin{array}{l}\text { Prevalence of } \\
\text { each year }\end{array}$} \\
\hline & $\begin{array}{l}\text { Ohgami- } \\
\text { yama Park }\end{array}$ & $\begin{array}{l}\text { Miyano } \\
\text { Beach }\end{array}$ & Suzaki & $\begin{array}{c}\text { Kominato } \\
\text { Beach }\end{array}$ & $\begin{array}{l}\text { Shigure } \\
\text { Dam }\end{array}$ & $\begin{array}{l}\text { Nakayama } \\
\text { Pass }\end{array}$ & $\begin{array}{l}\text { Ohgami-yama } \\
\text { Park/Suzaki* }\end{array}$ & Unknown & \\
\hline \multicolumn{10}{|l|}{$\begin{array}{l}\text { Cloacal samples } \\
\text { from green anoles }\end{array}$} \\
\hline October 2007 & $28(7 / 25)$ & - & $41.7(5 / 12)$ & - & - & - & - & - & $32.4(12 / 37)$ \\
\hline June 2008 & $43.8(7 / 16)$ & - & - & - & - & - & $37.9(11 / 29)$ & - & $40(18 / 45)$ \\
\hline July 2009 & $45.5(5 / 11)$ & $15.4(2 / 13)$ & - & - & $37.5(6 / 16)$ & $17.6(3 / 17)$ & - & - & $27.1(16 / 59)$ \\
\hline Sub total & $36.5(19 / 52)$ & $15.4(2 / 13)$ & $41.7(5 / 12)$ & - & $37.5(6 / 16)$ & $17.6(3 / 17)$ & $37.9(11 / 29)$ & - & $32.6(46 / 141)$ \\
\hline \multicolumn{10}{|l|}{$\begin{array}{l}\text { Intestinal samples } \\
\text { from frozen green } \\
\text { anoles }\end{array}$} \\
\hline $\begin{array}{l}\text { October } 2007 \& \\
\text { June } 2008\end{array}$ & - & - & - & - & - & - & - & $62.5(5 / 8)$ & $62.5(5 / 8)$ \\
\hline \multicolumn{10}{|l|}{$\begin{array}{l}\text { Fecal samples } \\
\text { from feral goats }\end{array}$} \\
\hline July 2009 & $0(0 / 4)$ & - & - & - & $33.3(1 / 3)$ & $20(1 / 5)$ & - & - & $16.7(2 / 12)$ \\
\hline \multicolumn{10}{|l|}{$\begin{array}{l}\text { Swab samples } \\
\text { from toilet bowls }\end{array}$} \\
\hline June 2008 & $10(1 / 10)$ & - & - & - & - & - & - & - & $10(1 / 10)$ \\
\hline July 2009 & $0(0 / 22)$ & $0(0 / 3)$ & - & $0(0 / 3)$ & - & - & - & - & $0(0 / 28)$ \\
\hline Sub total & $3.1(1 / 32)$ & $0(0 / 3)$ & - & $0(0 / 3)$ & - & - & - & - & $2.6(1 / 38)$ \\
\hline Total & $22.7(20 / 88)$ & $12.5(2 / 16)$ & $41.7(5 / 12)$ & $0(0 / 6)$ & $36.8(7 / 19)$ & $18.2(4 / 22)$ & $37.9(11 / 29)$ & $62.5(5 / 8)$ & $27.1(54 / 199)$ \\
\hline
\end{tabular}

* Ohgami-yama Park/Suzaki indicates that the sampling location could not be distinguished between these two areas.

samples could not be confirmed.

Salmonella spp. were isolated from $27.1 \%$ of the 199 samples collected from green anoles, feral goats and toilets; the overall isolation rate from 141 cloacal samples was $32.6 \%$. The specific rates divided by area are shown in Table 1. Of the eight intestinal contents, 5 were positive for Salmonella. The isolation rates of the 12 fecal samples from feral goats and 38 swabs from toilet bowls were $16.7 \%$ and $2.6 \%$, respectively. The specific rates for these samples divided by area are shown in Table 1.

There were no significant differences in Salmonella prevalence between the 3 sampling years $\left(\chi^{2}=1.928, P=0.381\right.$, $\mathrm{df}=2)$ or between the lizard cloacal samples $\left(\chi^{2}=3.788\right.$, $P=0.285$, df $=3)$, goat fecal samples $\left(\chi^{2}=1.440, P=0.487\right.$, $\mathrm{df}=2)$ or toilet bowl swabs $\left(\chi^{2}=0.193, P=0.908, \mathrm{df}=2\right)$.

The Salmonella Oranienburg serotype was isolated from $94.4 \%$ of 54 isolates (44 lizard cloacal samples and 1 goat fecal sample). The $S$. Weltevreden and $S$. Adelaide serotypes were also isolated from $1.9 \%$ and $3.7 \%$ of the 54 isolates, respectively. Table 2 shows the number and serotype-specific location of each isolate. Figure 2 shows the PFGE profiles of $S$. Oranienburg were classified into one type (more than $92.3 \%$ similarity).

The number of human cases of Salmonella infection associated with pet reptiles is increasing in the United States and Europe. Approximately $6 \%$ of human cases of Salmonella infection reported annually in the United States are attributed to exposure to reptiles, amphibians [15] or pet lizards [2]. There is also a report of a Japanese patient with
Salmonellosis caused due to exposure to a pet green iguana (Iguana iguana) [10]. The reported Salmonella prevalence in various pet lizards in Japan is $17.3 \%$ in 98 green iguanas [13], 62.7\% in 158 lizards [7] and $66.1 \%$ in 71 lizards of 16 species [17]. In contrast, the prevalence in wild lizards in Japan was shown to be only $4.1 \%$ in 434 individuals [7]. The relatively high Salmonella prevalence observed in green anoles on Chichi Island is comparable to these earlier studies, indicating that these lizards could become a reservoir and play an important role in the epidemiology of the pathogen. This is the first report of Salmonella infestation in alien lizards in Japan.

The population density of green anoles on Chichi Island is high (600-2,570 heads/10,000 $\mathrm{m}^{2}$ [18]) with the lizards roaming freely in and around houses, making it necessary for the community to prevent fecal pollution by the lizards and avoid contact. As many tourists visit the Ogasawara Islands annually [22], it is also necessary to introduce formal precautions against contracting Salmonella infection from the lizards.

In this study, we detected three serotypes of Salmonella. $S$. Oranienburg has been identified as the causative agent of food poisoning in humans [24] with a large-scale outbreak of the organism in main land of Japan in 1999 that affected 1634 people [16]. However, $S$. Oranienburg is an uncommon serovar in food poisoning cases in Japan, except on Okinawa Island, the southern part of Japan, and occasionally elsewhere [14]. $S$. Weltevreden and $S$. Adelaide are also uncommon Salmonella serotypes in Japan and often geographically 
Table 2. Serotypes of Salmonella isolated from samples grouped according to area

\begin{tabular}{|c|c|c|c|c|c|c|c|c|}
\hline \multirow{2}{*}{$\begin{array}{l}\text { Serotype (\% of } 54 \text { isolates) } \\
\text { and isolated samples }\end{array}$} & \multicolumn{7}{|c|}{ Place and number of each Salmonella serotype isolated } & \multirow[b]{2}{*}{ Total } \\
\hline & $\begin{array}{l}\text { Ohgami-yama } \\
\text { Park }\end{array}$ & $\begin{array}{l}\text { Miyano } \\
\text { Beach }\end{array}$ & Suzaki & $\begin{array}{l}\text { Nakayama } \\
\text { Pass }\end{array}$ & $\begin{array}{l}\text { Shigure } \\
\text { Dam }\end{array}$ & $\begin{array}{c}\text { Ohgami-yama Park/ } \\
\text { Suzaki }\end{array}$ & unknown & \\
\hline \multicolumn{9}{|l|}{ S. Oranienburg (94.4) } \\
\hline Cloacal sample from green anole & 18 & 2 & 5 & 2 & 6 & 11 & - & 44 \\
\hline Intestinal sample from green anole & - & - & - & - & - & - & 5 & 5 \\
\hline Fecal sample from feral goat & - & - & - & & 1 & & & 1 \\
\hline $\begin{array}{l}\text { swab sample from toilet bowl } \\
S . \text { Weltevreden (1.9) }\end{array}$ & 1 & - & - & - & - & - & - & 1 \\
\hline $\begin{array}{l}\text { Cloacal sample from green anole } \\
\text { S. Adelaide (3.7) }\end{array}$ & 1 & - & - & - & - & - & - & 1 \\
\hline Cloacal sample from green anole & - & - & - & 1 & - & - & - & 1 \\
\hline Fecal sample from feral goat & - & - & - & 1 & - & - & - & 1 \\
\hline
\end{tabular}

restricted [14]. Salmonella gastroenteritis has occurred sporadically in Chichi Island since 2000, though the source of these infections remains unclear. A study on 32 patients from this area showed that related isolates were $S$. Oranienburg (90.6\%), S. Gaminara (6.3\%) and $S$. Weltevreden $(3.1 \%)$ [12] with feral goats suspected as the source of infection. As the PFGE patterns indicated that detected $S$. Oranienburg in this study from green anoles, a toilet bowl swab and feral goat feces has the same source of infection and transmission [19], however, this S. Oranienburg strain was different from that in the 1999 food poisoning incident in Japan, this excludes the possibility that these isolates originated from human carriers [22].

We also found $S$. Oranienburg infections in feral goats from the island. These goats became feral in the 1940s before the introduction of green anoles [12]. As the habitats of the 2 species overlap, we suspect that there is transmission of Salmonella from goats to green anoles and vice versa. Fecal matter may also contribute to soil contamination with Salmonella, making transmission from feral goats to green anoles more likely. To our knowledge, there is no record of $S$. Oranienburg being isolated from green anoles with Salmonella subspecies isolated from wild lizards in Japan mainly being type IV (72.2\%), followed by type I $(27.8 \%)$ [7]. It is therefore difficult to determine whether the lizards were infected with Salmonella on the island or were already infected prior to invading the area.

Previous reports have suggested that introducing alien species poses risks and may negatively impact the health of humans, domestic animals and endemic species [5, 23]. It is therefore important to consider that alien species may be novel carriers or reservoirs for pathogens in areas in which they are introduced. Although our study did not determine the infection route, we consider that Salmonella is transmitted to green anoles by natural reservoirs, such as feral goats (spillover) and that the lizards spread the pathogen throughout the island (spill-back) [3]. During surveys and control of alien species, it is necessary to recognize that alien pathogens will invade along with host species and that endemic pathogens may be acquired or amplified by the alien species.
ACKNOWLEDGMENTS. We thank Masaaki Takiguci and Yuji Takafuji of the Japan Wildlife Research Center for helping capture and sample the green anoles, Ikuno Hayashida, Yuri Endo, Emi Sasaki and Akiko Mitsuhashi of Nihon University and Azabu University for helping capture the green anoles and bacterial culture and Masafumi Nukina of Kobe Municipal Environmental Hygiene Research Center for helping salmonella serotyping. This study was supported by Grant-in-Aid for challenging Exploratory Research (24651270), a Nihon University Research Grant, Academic Frontier Project "Surveillance and control for zoonoses," and the "High-Tech Research Center" Project for Private University from MEXT of Japan for KM.

\section{REFERENCES}

1. Beletsky, L. 2000. p. 416. Hawaii The Ecotravellers Wildlife Guide. Academic Press, London.

2. Cooke, F. J., De Pinna, E., Maguire, C., Guha, S., Pickard, D. J., Farrington, M. and Threlfall, E. J. 2009. First report of human infection with Salmonella enterica serovar Apapa resulting from exposure to a pet lizard. J. Clin. Microbiol. 47: 2672-2674. [Medline] [CrossRef]

3. Daszak, P., Cunningham, A. A. and Hyatt, A. D. 2000. Emerging infectious diseases of wildlife-Threats to biodiversity and human health. Science 287: 443-449. [Medline] [CrossRef]

4. Fritts, T. and Rodda, G. 1998. The role of introduced species in the degradation island ecosystems: A case history of Guam. Annu. Rev. of Ecol. Syst. 29: 113-140. [CrossRef]

5. Goldberg, S. R. and Bursey, C. R. 2000. Transport of helminths to Hawaii via the brown anole, Anolis sagrei (Polychrotidae). $J$. Parasitol. 86: 750-755. [Medline]

6. Haddock, R. L., Nocon, F. A., Santos, E. A. and Taylor, T. G. 1990. Reservoirs and vehicles of Salmonella infection on Guam. Environ. Int. 16: 11-16. [CrossRef]

7. Hayashidani, H. and Iwata Nakadai, A. 2008. Salmonella in reptiles. Modern Media 54: 165-170 (in Japanese).

8. Hunter, S. B., Vauterin, P., Lambert-Fair, M. A., Van Duyne, M. S., Kubota, K., Graves, L., Wrigley, D., Barrett, T. and Ribot, E. 2005. Establishment of a universal size standard strain for use with the PulseNet standardized pulsed-field gel electrophoresis protocols: converting the national databases to the new size stan- 
dard. J. Clin. Microbiol. 43: 1045-1050. [Medline] [CrossRef]

9. Ikeda, T., Asano, M., Matoba, Y. and Abe, G. 2004. Present status of invasive alien raccoon and its impact in Japan. Glob. Environ. Res. 8: 125-131.

10. Infectious, A. S. R. 2010. http://idsc.nih.go.jp/iasr/26/310/ kj3102.html. Accessed December 2010 (in Japanese).

11. Inoue, K., Kabeya, H., Fujita, H., Makino, T., Asano, M., Inoue, S., Inokuma, H., Nogami, S. and Maruyama, S. 2011. Serological survey of five zoonoses, Scrub typhus, Japanese spotted fever, Tularemia, Lyme Disease, and Q Fever, in feral raccoons (Procyon lotor) in Japan. Vector Borne Zoonotic Dis. 11: 15-19. [Medline] [CrossRef]

12. Inoue, S., Saikawa, N., Nakagawa, S. and Shinomiya, M. 2006. Fecal examination of feral goats on Ogasawara Islands. pp. 194-195. In: Proceedings of the Society of Public Health, Social Welfare and Medical Services, Tokyo Metropolitan Government 2006 (in Japanese).

13. Kabeya, H., Fujita, M., Morita, Y., Yokoyama, E., Yoda, K., Yamauchi, A., Murata, K. and Maruyama, S. 2008. Salmonella, Pasteurella and Staphylococcus infection in pet iguanas. J. Jpn. Vet. Med. Assoc. 61: 70-74 (in Japanese with English summary).

14. Kudaka, J., Itokazu, K., Taira, K., Iwai, A., Kondo, M., Susa, T. and Iwanaga, M. 2006. Characterization of Salmonella isolated in Okinawa, Japan. Jpn. J. Infect. Dis. 59: 15-19. [Medline]

15. Mermin, J., Hutwagner, L., Vugia, D., Shallow, S., Daily, P., Bender, J., Koehler, J., Marcus, R. and Angulo, F. J., Emerging Infections Program FoodNet Working Group. 2004. Reptiles, amphibians, and human Salmonella infection: a populationbased, case-control study. Clin. Infect. Dis. 38: S253-261. [Medline] [CrossRef]

16. Miyakawa, S., Takahashi, K., Hattori, M., Itoh, K., Kurazono, T. and Amano, F. 2006. Outbreak of Salmonella Oranienburg infection in Japan. J. Environ. Biol. 27: 157-158. [Medline]

17. Nakadai, A., Kuroki, T., Kato, Y., Suzuki, R., Yamai, S., Yaginuma, C., Shiotani, R., Yamanouchi, A. and Hayashidani, H. 2005. Prevalence of Salmonella spp. in pet reptiles in Japan. J. Vet. Med. Sci. 67: 97-101. [Medline] [CrossRef]

18. Okochi, I., Yoshimura, M., Abe, T. and Suzuki, H. 2010. High population densities of an exotic lizard, Anolis carolinensis and its possible role as a pollinator in the Ogasawara Islands. pp. 71-74. In: Restoring the Oceanic Island Ecosystem: Impact and Management of Invasive Alien Species in the Bonin Islands (Kawakami, K. and Okochi, I. eds.), Springer, Tokyo.

19. Tenover, F. C., Arbeit, R. D., Goering, R. V., Mickelsen, P. A., Murray, B. E., Persing, D. H. and Swaminathan, B. 1995. Interpreting chromosomal DNA restriction patterns produced by pulsed-field gel electrophoresis: criteria for bacterial strain typing. J. Clin. Microbiol. 33: 2233-2239. [Medline]

20. The Invasive Species Specialist Group (ISSG) of the IUCN Species Survival Commission 2010. interface.creative.auckland. ac.nz/database/welcome. Accessed December 2010.

21. Toda, M., Takahashi, H., Nakagawa, N. and Sukigara, N. 2010. Ecology and control of the green anole (Anolis carolinensis), an invasive alien species on the Ogasawara Islands. pp. 145-152. In: Restoring the Oceanic Island Ecosystem: Impact and Management of Invasive Alien Species in the Bonin Islands (Kawakami, K. and Okochi, I. eds.), Springer, Tokyo.

22. Tokyo Metropolitan Government 2010. www.metro.tokyo.jp/ INET/BOSHU/2009/09/22j9h300.htm. Accessed December 2010 (in Japanese).

23. Rushton, S. P., Lurz, P. W., Gurnell, J., Nettleton, P., Bruemmer, C., Shirley, M. D. and Sainsbury, A. W. 2006. Disease threats posed by alien species: the role of a poxvirus in the decline of the native red squirrel in Britain. Epidemiol. Infect. 134: 521-533. [Medline] [CrossRef]

24. Werber, D., Dreesman, J., Feil, F., Van, T. U., Fell, G., Ethelberg, S., Hauri, A. M., Roggentin, P., Prager, R., Fisher, I. S., Behnke, S. C., Bartelt, E., Weise, E., Ellis, A., Siitonen, A., Andersson, Y., Tschape, H., Kramer, M. H. and Ammon, A. 2005. International outbreak of Salmonella Oranienburg due to German chocolate. BMC. Infect. Dis. 5: 7. [Medline] [CrossRef]

25. Yamada, F. and Sugimura, K. 2004. Negative impact of an invasive small Indian mongoose Herpestes javanicus on native wildlife species and evaluation of a control project in AmamiOhshima and Okinawa Islands, Japan. Glob. Environ. Res. 8: $117-124$. 